\title{
Linking phytotechnologies to bioeconomy; varietal screening of high biomass and energy crops for phytoremediation of $\mathrm{Cr}$ and $\mathrm{Cu}$ contaminated soils
}

\author{
Filip Pošćić, ${ }^{1-3}$ Guido Fellet, ${ }^{1}$ Massimo Fagnano, ${ }^{2}$ Nunzio Fiorentino, ${ }^{2}$ Luca Marchiol ${ }^{1}$ \\ ${ }^{1}$ DI4A - Department of Agriculture, Food, Environment and Animal Sciences, University of Udine, Italy; \\ ${ }^{2}$ Department of Agricultural Sciences, University of Naples Federico II, Portici (NA), Italy; \\ ${ }^{3}$ Institute for Adriatic Crops and Karst Reclamation, Split, Croatia
}

\begin{abstract}
Enerbiochem was a project devoted to study new strategies of industrial valorisation of high biomass crops grown on brownfields or contaminated soils not suitable for food production. Chromium and copper accumulation and toxicity were examined in different species of agronomic interest. Cultivars of Brassica carinata A. Braun (7), Brassica juncea (L.) Czern. (4), Brassica napus L. (4), Raphanus sativus L. (4), inbred lines of Helianthus annuus L. (6) and cultivars of Nicotiana tabacum L. (3) were screened for the best genetic materials to be used with the aims: i) to produce the highest biomass in contaminated soils; and ii) possibly to phytoremediate them. $\mathrm{Cr}$ and $\mathrm{Cu}$ accumulation in shoots were evaluated on 16 days old plants grown for additional 5 days in the presence of either $\mathrm{Cr}(60 \mu \mathrm{M})$ or $\mathrm{Cu}(2 \mu \mathrm{M})$ in hydroponic.
\end{abstract}

Correspondence: Luca Marchiol, DI4A - Department of Agriculture, Food, Environment and Animal Sciences, University of Udine, via delle Scienze 208, I-33100 Udine, Italy.

E-mail: luca.marchiol@uniud.it

Key words: Chromium; copper; accumulation; plant biomass; biomass valorisation.

Acknowledgements: this research was part of the project $P O N 01$ 01966 ENERBIOCHEM supported by EU and MIUR. The authors would like to acknowledge the Centre for Genetic Resources, the Netherlands (CGN), Wageningen (NL); Centro per la Ricerca e l'analisi dell'Economia Agraria (CREA) ex Consiglio per la Ricerca e la sperimentazione in Agricoltura (CRA) - Unità di ricerca per le Colture Alternative al Tabacco (CAT), Scafati (I); and Maurizio Turi from Centro Universitario di Servizi per la Ricerca e la Didattica in Agricoltura (CUSA), University of Udine, Udine (I) for providing the seed accessions. The contribution of Nicola Novello, Ingrid Cigliani is acknowledged, as well.

Received for publication: 23 December 2017.

Revision received: 17 July 2018.

Accepted for publication: 3 September 2018.

(C) Copyright F. Pošćić et al., 2019

Licensee PAGEPress, Italy

Italian Journal of Agronomy 2019; 14:1176

doi:10.4081/ija.2019.1176

This article is distributed under the terms of the Creative Commons Attribution Noncommercial License (by-nc 4.0) which permits any noncommercial use, distribution, and reproduction in any medium, provided the original author(s) and source are credited.
They were characterised for $\mathrm{Cr}$ and $\mathrm{Cu}$ concentrations in roots and shoots, shoot biomass, and total chlorophyll as well.

Shoot biomass was significantly lower in Brassica species than in R. sativus, H. annuus and N. tabacum under $\mathrm{Cr}$ treatments. On the contrary, under $\mathrm{Cu}$ treatments, $N$. tabacum produced the lowest biomass in respect to other species. Potentially toxic element concentrations varied among genetic material and some genetic material resulted less affected (higher chlorophyll content and shoot biomass) even under higher $\mathrm{Cu}$ or $\mathrm{Cr}$ concentrations in shoot. Potential candidates within each species, to be used for coupling phytoremediation and biomass production on slightly $\mathrm{Cr}-\mathrm{Cu}$ potentially contaminated soils are listed.

\section{Introduction}

The greatest challenge of this century will be the transition from a fossil-based economy to bioeconomy. That is needed in response to several global mega-trends such as: i) fast-growing global population and higher life expectancy; ii) rise of food production and water demand; iii) high dependence on fossil-based resources; iv) needing of a diversified energy supply options; v) increasing greenhouse gases emission; vi) increasing land use competition; vii) land and water resource pollution (Nita et al., 2013).

Driven by environmental concerns, an increasing focus is paid worldwide to sustainable technologies which are part of the concept of a bio-based economy or bioeconomy (EC, 2012). Bioeconomy is an economy in which bio-based materials instead of fossil-based ones are used for the production of energy, transport fuels, chemicals and many other materials (Prasad, 2016). According to European Community (2012) significant growth is expected to arise from sustainable primary production, food processing and industrial biotechnology and biorefineries, which lead to new bio-based industries, transform existing ones, and open new markets for bio-based products. With regard to land pollution, several remediation technologies are available to clean up or securing the contaminated sites. Extensive studies over the last three decades demonstrated the potential of plant based technologies (phytotechnologies) as biological remediation techniques (Fagnano, 2016). Being more energy-efficient and less disruptive to contaminated sites they emerged as viable alternatives to conventional remediation techniques. The traditional term phytoremediation has been recently associated with the term phytotechnologies. In addition to the degradation and/or removal of contaminants, phytotechnology also includes techniques such as stabilisation and volatilisation of pollutants, terminate the exposure pathways of pollutants, thus securing the sites (Fagnano, 2017).

The expected take-off of the bioeconomy will lead to 
increased demand for biomass. The use of brownfields and marginal lands or contaminated sites to produce non-food biomasses for energy valorisation or chemical industry through plants, which are able to grow and to develop healthy in such environments is a feasible option. While remediating contaminated substrates or wastewaters, phytotechnologies provide plant biomass to be reused that can be used as renewable energy sources, green fine chemistry, bioplastics, etc. (Prasad, 2014). That implies that phytotechnology, beyond its primary role, is attractive also as an additional source of biomass and it can be considered as an integral part of sustainable development and bioeconomy (Prasad, 2016). However, development of economically sound valorisation pathways for complete chain of phytoproducts of value addition and value chain from phytotechnologies would go a long way (Grison 2015; van der Ent et al. 2015).

The multidisciplinary project PON01_01966 ENERBIOCHEM - Agricultural and industrial supply chain with energetic high efficiency for the setup of bio-compatible production processes of energy and bio-chemicals from renewable sources and for the improvement of the local areas was aimed at developing integrated agro-industrial chain processes to produce bio-fuel (i.e. bioethanol and bio-diesel) from renewable sources in respectively marginal lands subjected to erosion (Fagnano et al., 2015) and polluted soils (Fiorentino et al., 2013). Our group was involved in studies regarding two agro-industrial biomass chains, respectively from oleaginous crops (Brassica species, Helianthus annuus L., Nicotiana tabacum L) and ligno-cellulosic field crops (Sorghum bicolor L., Arundo donax L., and Cynara cardunculus L.), subjected to $\mathrm{Cr}$ and $\mathrm{Cu}$ contamination.

Chromium $(\mathrm{Cr})$ and copper $(\mathrm{Cu})$ are among the most widely used heavy metals in industries which effluents contain ionic $\mathrm{Cr}$ and $\mathrm{Cu}$ in high concentrations which can accumulate in soils and cause serious environmental pollution (Costa, 2003; WHO, 2003a, 2003b).

Chromium is a potentially toxic element (PTE) non-essential in plant physiology and present in environment mostly in hexavalent or trivalent form (Marschner, 2012; Shanker et al., 2005). Both hexavalent $\left(\mathrm{CrO}_{4}^{2-}, \mathrm{HCrO}^{4-}\right.$ and $\left.\mathrm{Cr}_{2} \mathrm{O}_{7}{ }^{2}\right)$ and trivalent $\left(\mathrm{Cr}^{3+}\right.$ and $\mathrm{CrOH}^{2+}$ ) chromium species are present in industrial waste solutions (Shanker et al., 2005; Miretzky and Cirelli, 2010). However, $\mathrm{Cr}$ toxicity in plants depends on its valence state and hexavalent chromium is much more toxic than trivalent chromium (Shanker et al., 2005). Moreover, Cr(VI) is considered hazardous to public health due to its mutagenic and carcinogenic properties (Shanker et al., 2005).

Copper is a PTE essential in small amounts for plant metabolism and can be present as $\mathrm{Cu}^{+}$or $\mathrm{Cu}^{2+}$ under physiological conditions (Marschner, 2012). While $\mathrm{Cu}$ is an essential micronutrient, prolonged exposure to the metal causes adverse health effects in both plants and animals (WHO, 2003b). Large acute doses can potentially produce fatal effects in humans (WHO, 2003b).

The aim of this research was to test a number of genetic materials from six different species of agronomical interest (Brassica carinata, Brassica juncea, Brassica napus, Helianthus annuus, Nicotiana tabacum and Raphanus sativus) for their biomass and $\mathrm{Cr}-\mathrm{Cu}$ accumulation capacities under plant exposition to slightly toxic $\mathrm{Cr}$ or $\mathrm{Cu}$ concentrations in hydroponic system. By determining parameters such as chlorophyll content, shoot dry weight, along with $\mathrm{Cr}$ and $\mathrm{Cu}$ accumulation in the shoots, the phytotoxic effects of these two heavy metals were quantified with the aim to determine if these species display sufficient tolerance and metal accumulating ability to be used for phytoremediation and biomass purposes on slightly $\mathrm{Cr}-\mathrm{Cu}$ polluted soils.

\section{Materials and methods}

Seeds of different genetic material from Brassica carinata A. Braun, Brassica juncea (L.) Czern., Brassica napus L., Raphanus sativus L., Helianthus annuus L. and Nicotiana tabacum L. (Table 1) were sown in a garden peat soil and left for ten days in a growth chamber. Seedlings were then transferred to aerated hydroponic culture in 1-L polyethylene pots (one plant per pot) according to Mei et al. (2002) with slight modification. In particular, our culture contained a modified half-strength Hoagland's solution composed of $3 \mathrm{mM} \mathrm{KNO}_{3}, 2 \mathrm{mM} \mathrm{Ca}\left(\mathrm{NO}_{3}\right)_{2}, 1 \mathrm{mM} \mathrm{NH}_{4} \mathrm{H}_{2} \mathrm{PO}_{4}, 0.5 \mathrm{mM}$ $\mathrm{MgSO}_{4}, 20 \mu \mathrm{M}$ Fe(Na)-EDTA, $1 \mu \mathrm{M} \mathrm{KCl}, 25 \mu \mathrm{M} \mathrm{H}_{3} \mathrm{BO}_{3}, 2 \mu \mathrm{M}$ $\mathrm{MnSO}_{4}, 2 \mu \mathrm{M} \mathrm{ZnSO}_{4}, 0.1 \mu \mathrm{M} \mathrm{CuSO}_{4}$ and $0.1 \mu \mathrm{M}\left(\mathrm{NH}_{4}\right)_{6} \mathrm{Mo}_{7} \mathrm{O}_{24}$ in demineralised water buffered with $2 \mathrm{mM}$ 2-N-morpholino-ethanesulfonic acid (MES), $\mathrm{pH} 5.5$, adjusted with $\mathrm{KOH}$. Plants were grown in a growth chamber $\left(22 / 16^{\circ} \mathrm{C}\right.$ day/night; light intensity 220 $\mu \mathrm{E} \mathrm{m}^{-2} \mathrm{~s}^{-1}, 14 \mathrm{~h} \mathrm{day}^{-1}$; relative humidity $70-80 \%$ ).

After six days of pre-culture, plants were transferred to the test solution, which was of the same background composition as the pre-culture solution, but with Fe-EDDHA instead of $\mathrm{Fe}(\mathrm{Na})$ EDTA, to avoid $\mathrm{Cu}$-EDTA complex formation, owing to displacement of $\mathrm{Fe}^{(\mathrm{III})}$ (Lucena and Chaney, 2007). Plants were exposed to either $2 \mu \mathrm{M} \mathrm{Cu}\left(0.127 \mathrm{mg} \mathrm{L}^{-1}\right)$ or $60 \mu \mathrm{M} \mathrm{Cr}\left(3.12 \mathrm{mg} \mathrm{L}^{-1}\right)$ obtained from $\mathrm{CuSO}_{4}$ and $\mathrm{K}_{2} \mathrm{Cr}_{2} \mathrm{O}_{7}$ respectively. These concentrations were chosen after literature screening (Marchiol et al., 2006; Shahbaz et al., 2010; Terzi and Y1ld1z, 2015). While contaminated real soils are expected to have a range of $\mathrm{pH}$ we used a slightly acid $\mathrm{pH}$ typically applied in hydroponic toxicity experiments in order to keep all the nutrients available and to avoid precipitation (Marchiol et al., 2006). We also choose to test $\mathrm{Cr}$ (VI) despite the most frequent $\mathrm{Cr}(\mathrm{III})$ because $\mathrm{Cr}(\mathrm{VI})$ is more toxic and with carcinogenic properties (Mei et al., 2002). Plants were grown in treatment solution for additional six days (one plant per pot, three plants per treatment per genetic material in a randomised design). The treatment solutions were refreshed after three days in order to keep concentrations of elements in solution constant.

Prior harvesting, small disk ( $5 \mathrm{~mm}$ in diameter) from one adult leaf of each plant was collected in $2 \mathrm{~mL}$ Eppendorf, grinded under liquid nitrogen and re-suspended in $2 \mathrm{~mL}$ of $80 \%$ acetone (Sudhakar et al., 2016). After ultracentrifugation, total chlorophyll content was determined using a spectrophotometer (Pharmacia Biotech, Novaspec II, 80-2088-54) (Sudhakar et al., 2016).

\section{ICP-OES analysis of chromium and copper in soil and plant fractions}

Immediately after harvesting plant specimens were divided into shoots and roots and the latter were carefully rinsed with icecold $\mathrm{Pb}\left(\mathrm{NO}_{3}\right)_{2}$ for 30 min to desorb metals from the root free space and then blotted with paper tissue (Cestone et al., 2010). Shoots and roots were oven-dried for $24 \mathrm{~h}$ at $105^{\circ} \mathrm{C}$ and total shoot dry biomass was measured through technical-balance. Subsequently, roots and shoots were acid-digested in a microwave oven (CEM, MARS Xpress) according to the USEPA 3052 method (USEPA, 1995). After mineralisation, extracts were filtered $(0.45 \mathrm{~mm}$ PTFE), diluted and analysed. Elemental analysis was performed through ICP-AES (Varian Inc., Vista MPX) and the accuracy of the analytical procedure was checked running standards every 20 samples. Quality control was conducted using Y as the internal standard, reagent blank samples, and triplicates reading for each sample. Detection limits were: $2 \mu \mathrm{g} \mathrm{L}^{-1}$ and $4 \mu \mathrm{g} \mathrm{L}-1$ for $\mathrm{Cr}$ and $\mathrm{Cu}$ respectively. Total shoot accumulation of $\mathrm{Cr}$ and $\mathrm{Cu}$ was estimated as the product of shoot concentration times biomass. 


\section{Data analysis}

Statistical analysis used the nested ANOVA (genetic material nested within species) according to Sokal and Rohlf (2010). A posteriori comparison of individual means was based on the minimum significant difference (MSD) method obtained from the T statistic (Sokal and Rohlf, 2010). Calculations were made through PC spread sheet utilities.

\section{Results}

\section{Shoot biomass and development}

Different genetic material within Raphanus sativus, Helianthus annuus and Nicotiana tabacum developed higher shoot biomass while all the varieties of Brassica spp. except the B. carinata 79444 have shown a remarkably and significantly lowest shoot biomass development under $\mathrm{Cr}$ exposition (Table 2). B. carinata 79444 biomass was not significantly different from $H$. annuus $28 \mathrm{R}$ Mt and $R$. sativus Hazera Red but it would be expected a larger difference if the experiment would stay longer. $R$. sativus varieties Nabo Amazela, Pegletta and Cavalrondo, and the $H$. annuus inbred line R 1954/1 developed the significantly highest biomass among genetic material (Table 2).

In the $\mathrm{Cu}$ experiment, all the tobacco cultivars showed the lowest biomass among analysed genetic material. On the other side, no other plants show a clear species specific response. Rather shoot biomass was very variable among different genetic material (Table 3). In the
$\mathrm{Cu}$ experiment, the biggest shoot biomass was developed by H. annuus $3620 \mathrm{MT}$, on average nine times bigger then the tobacco biomass which was the lowest (Table 2). However, the tobacco inbred lines were not significantly different from three of $H$. annuиs inbred lines (R 1954/1, R 569 and RT2) and R 569 was not significantly different from the inbred line $3620 \mathrm{MT}$ biomass. The great variability in shoot biomass between individual plants and the genetic material is probably due to a complicated relationship between species and the genetic material.

Leaf chlorophyll content in all $\mathrm{Cr}$ treated plants except $N$. tabacum cultivars was little affected relatively to the corresponding control leaves with an average of $96 \%$ of chlorophyll content relatively to that present in control plants. Only in $N$. tabacum cultivars the relative chlorophyll content was lower, although not always to a significant extent, being only $47 \%$ of that present in control plants. This is giving insights that the $\mathrm{Cr}$ test concentration chosen $(60 \mu \mathrm{M})$ was still under partial plant homeostasis control in all samples except tobacco. Tobacco plants are thus resulting to be very sensitive to $\mathrm{Cr}$. Moreover, some genetic material as B. carinat $a$ varieties B.car 0.99 , BRK35 and SVP nr.12, B. juncea variety Newton, H. annuus inbred lines 28 R MT, R 1954/1, R 569 and R T2, and R. sativus variety Hazera Red, although not significantly, shown an increased leaf chlorophyll content relatively to corresponding control leaves (Table 2).

Leaf chlorophyll content of $\mathrm{Cu}$ treated plants relatively to the corresponding control leaves, was generally lower with an average of $92 \%$ of chlorophyll content relatively to that present in control plants. Moreover, the relative leaf chlorophyll content was not significantly different among genetic materials in $\mathrm{Cu}$ experiment.

Table 1. Genetic material description: species name, accession name of different genetic material and their source are reported.

\begin{tabular}{|c|c|c|}
\hline Species & Accession name & Source \\
\hline Brassica carinata & $\begin{array}{l}79444 \\
\text { B.car } 0.99 \text { (CGN04028) } \\
\text { BRK35 } \\
\text { Gommenzer 1 (CGN03966) } \\
\text { Gommenzer } 2 \text { (CGN04019) } \\
\text { L194252 } \\
\text { SVP nr.12 (CGN04025) }\end{array}$ & $\begin{array}{l}\text { DI4A, University of Udine, Udine (I) } \\
\text { CGN, Wageningen (NL) } \\
\text { DI4A, University of Udine, Udine (I) } \\
\text { CGN, Wageningen (NL) } \\
\text { CGN, Wageningen (NL) } \\
\text { CGN, Wageningen (NL) } \\
\text { CGN, Wageningen (NL) }\end{array}$ \\
\hline Brassica juncea & $\begin{array}{l}\text { Newton (CGN19972) } \\
\text { Primus (CGN06615) } \\
\text { Trowse (CGN19973) } \\
\text { Vitasso (CGN19974) }\end{array}$ & $\begin{array}{l}\text { CGN, Wageningen (NL) } \\
\text { CGN, Wageningen (NL) } \\
\text { CGN, Wageningen (NL) } \\
\text { CGN, Wageningen (NL) }\end{array}$ \\
\hline Brassica napus & $\begin{array}{l}\text { Buko (CGN18958) } \\
\text { Cobra (CGN18960) } \\
\text { Pulsar } \\
\text { Ramses (CGN17382) }\end{array}$ & $\begin{array}{l}\text { CGN, Wageningen (NL) } \\
\text { CGN, Wageningen (NL) } \\
\text { CGN, Wageningen (NL) } \\
\text { CGN, Wageningen (NL) }\end{array}$ \\
\hline Helianthus annuus & $\begin{array}{l}\text { Inbred line } 28 \mathrm{R} \mathrm{MT} \\
\text { Inbred line } 3620 \mathrm{MT} \\
\text { Inbred line } 458 \mathrm{MT} \\
\text { Inbred line R 1954/1 } \\
\text { Inbred line R 569 } \\
\text { Inbred line R T2 } \\
\end{array}$ & $\begin{array}{l}\text { DI4A, University of Udine, Udine (I) } \\
\text { DI4A, University of Udine, Udine (I) } \\
\text { DI4A, University of Udine, Udine (I) } \\
\text { DI4A, University of Udine, Udine (I) } \\
\text { DI4A, University of Udine, Udine (I) } \\
\text { DI4A, University of Udine, Udine (I) }\end{array}$ \\
\hline Nicotiana tabacum & $\begin{array}{l}\text { G165 (Bright type) } \\
\text { G19 (Bright type) } \\
\text { P2B (Oriental type) }\end{array}$ & $\begin{array}{l}\text { CRA-CAT, Scafati (I) } \\
\text { CRA-CAT, Scafati (I) } \\
\text { CRA-CAT, Scafati (I) }\end{array}$ \\
\hline Raphanus sativus & $\begin{array}{l}\text { Cavalrondo (CGN20741) } \\
\text { Hazera Red (CGN20758) } \\
\text { Nabo Amazela (CGN06912) } \\
\text { Pegletta (CGN06952) }\end{array}$ & $\begin{array}{l}\text { CGN, Wageningen (NL) } \\
\text { CGN, Wageningen (NL) } \\
\text { CGN, Wageningen (NL) } \\
\text { CGN, Wageningen (NL) } \\
\end{array}$ \\
\hline
\end{tabular}

CGN accession codes are given between brackets. 
This can give an indication of similar stress response among the different analysed species. However, in some plants such as B. carinata variety BRK35, B. juncea varieties Primus, Trowse and Vitasso, H. annuus inbred line R 1954/1, N. tabacum cultivar P2B, and $R$. sativus variety Cavalrondo, leaf chlorophyll content, although not significantly, was slightly higher than the corresponding control leaves (data not shown).

\section{Roots and shoots potentially toxic element concentrations}

Chromium concentrations in the roots were similar and not significantly different among all genetic material with an overall mean of $2269 \mu \mathrm{g} \mathrm{g}^{-1}$ (Table 2). Similarly, Cr concentrations in the shoots varied little among genetic material. Although not significantly different from the majority of genetic materials, the lowest $\mathrm{Cr}$ concentrations in the shoots were found in H. annuus (on average $6.82 \mu \mathrm{g} \mathrm{g}^{-1}$ ). The no significance can be, however due to high variation within replicates and further experiments should assess this. The highest $\mathrm{Cr}$ concentration in shoots relatively to the other genetic material was found in $R$. sativus variety Hazera Red with a mean value of $35.4 \mu \mathrm{g} \mathrm{g}^{-1}$ which was significantly different from all the other means except from the B. juncea variety Primus which showed also notable $\mathrm{Cr}$ concentration in the shoots of $21.9 \mu \mathrm{g} \mathrm{g}^{-1}$ on average (Table 2).

However, there was a clear restriction to $\mathrm{Cr}$ translocation into the shoots for all the genetic material and the translocation coefficients (shoot concentration to root concentration ratio) was not sig- nificantly different among genetic materials and approximately 0.0056 - that is only $0.56 \%$ of $\mathrm{Cr}$ in roots was present in shoots.

Copper concentration in the roots was highest in N. tabacum cultivars while the lowest in B. carinata variety 79444 . There was no clear species-specific response in root $\mathrm{Cu}$ concentrations with great variability among genetic material within species (Table 3). Given the great variability among replicates, significant differences among genetic material and species was hard to be detected. N. tabacum cultivars G19 and P2B had significantly higher root $\mathrm{Cu}$ concentrations respect to all the other genetic materials reaching mean values of 1525.1 and $1105.3 \mu \mathrm{g} \mathrm{g}^{-1}$ of $\mathrm{Cu}$ in roots respectively. Also in the shoots the higher $\mathrm{Cu}$ concentration were found in N. tabacum cultivars which were significantly higher from the other genetic materials with an average of $87.4 \mu \mathrm{g} \mathrm{g}^{-1}$ of $\mathrm{Cu}$ in shoots. However, there was also for $\mathrm{Cu}$ a clear restriction to its translocation into the shoots for all the species and the translocation coefficients was not significantly different among genetic materials and approximately 0.13 - that is $13 \%$ of $\mathrm{Cu}$ in roots was present in shoots.

\section{Shoot heavy metal accumulation}

To assess the effectiveness of the different genetic material within species for phytoremediation of $\mathrm{Cr}$ and $\mathrm{Cu}$ polluted soils taking into account also their shoot biomass for energy valorisation or chemical industry, total shoot accumulation (plant aboveground biomass multiplied by the PTE concentration) was calculated for $\mathrm{Cr}$ and $\mathrm{Cu}$ (Table 2 and 3 respectively).

Table 2. Cr concentration in roots and shoots $\left(\mu \mathrm{g} \mathrm{g}^{-1}\right.$ d.w.), shoot d.w. ( $\mathrm{mg}$ ), Cr accumulation in the shoots ( $\mu \mathrm{g}$ d.w.) and relative chlorophyll content (\% of control plants) of 28 analysed accessions from six different species (mean $\pm S E, n=3$ ) after exposure to $60 \mu \mathrm{M} C r$ for six days.

\begin{tabular}{|c|c|c|c|c|c|c|}
\hline Species & Accession name & Root Cr & Shoot Cr & Shoot d.w. & $\begin{array}{l}\text { Shoot } \mathrm{Cr} \\
\text { accumulation }\end{array}$ & $\begin{array}{l}\text { Relative chlorophyll } \\
\text { content }\end{array}$ \\
\hline Brassica carinata & $\begin{array}{l}79444 \\
\text { B.car } 0.99 \text { (CGN04028) } \\
\text { BRK35 } \\
\text { Gommenzer } 1 \\
\text { Gommenzer } 2 \\
\text { L194252 } \\
\text { SVP nr.12 }\end{array}$ & $\begin{array}{l}2331^{\mathrm{a}} \\
2125^{\mathrm{a}} \\
2224^{\mathrm{a}} \\
2205^{\mathrm{a}} \\
2300^{\mathrm{a}} \\
2666^{\mathrm{a}} \\
2086^{\mathrm{a}}\end{array}$ & $\begin{array}{c}12.4^{\mathrm{bcd}} \\
13.6^{\mathrm{bcd}} \\
11.6^{\mathrm{bcd}} \\
11.2^{\mathrm{bcd}} \\
9.2^{\mathrm{bcd}} \\
13.9^{\mathrm{bcd}} \\
9.9^{\mathrm{bcd}}\end{array}$ & $\begin{array}{l}21.7^{\mathrm{f}} \\
12.1^{\mathrm{f}} \\
14.9^{\mathrm{f}} \\
15.2^{\mathrm{f}} \\
15.3^{\mathrm{f}} \\
20.0^{\mathrm{f}} \\
20.7^{\mathrm{f}}\end{array}$ & $\begin{array}{l}0.273^{\mathrm{de}} \\
0.163^{\mathrm{e}} \\
0.178^{\mathrm{e}} \\
0.167^{\mathrm{e}} \\
0.151^{\mathrm{e}} \\
0.258^{\mathrm{de}} \\
0.201^{\mathrm{de}}\end{array}$ & $\begin{array}{l}83.9^{\mathrm{abc}} \\
110.8^{\mathrm{abc}} \\
132.7^{\mathrm{ab}} \\
80^{\mathrm{abc}} \\
74.6^{\mathrm{abc}} \\
90.6^{\mathrm{abc}} \\
143.9^{\mathrm{a}}\end{array}$ \\
\hline Brassica juncea & $\begin{array}{l}\text { Newton } \\
\text { Primus } \\
\text { Trowse } \\
\text { Vitasso }\end{array}$ & $\begin{array}{l}2201^{\mathrm{a}} \\
2199^{\mathrm{a}} \\
2406^{\mathrm{a}} \\
2733^{\mathrm{a}}\end{array}$ & $\begin{array}{l}12.0^{\mathrm{bcd}} \\
21.9^{\mathrm{ab}} \\
14.3^{\mathrm{bcd}} \\
12 . .^{8 \mathrm{bcd}}\end{array}$ & $\begin{array}{l}15.7^{\mathrm{f}} \\
19.3^{\mathrm{f}} \\
15.5^{\mathrm{f}} \\
18.2^{\mathrm{f}}\end{array}$ & $\begin{array}{l}0.186^{\text {de }} \\
0.404^{\text {de }} \\
0.216^{\text {de }} \\
0.206^{\text {de }}\end{array}$ & $\begin{array}{l}107.2^{\mathrm{abc}} \\
89.3^{\mathrm{abc}} \\
79.1^{\mathrm{abc}} \\
56.8^{\mathrm{bc}}\end{array}$ \\
\hline Brassica napus & $\begin{array}{l}\text { Buko } \\
\text { Cobra } \\
\text { Pulsar } \\
\text { Ramses }\end{array}$ & $\begin{array}{l}2322^{\mathrm{a}} \\
2120^{\mathrm{a}} \\
1831^{\mathrm{a}} \\
2485^{\mathrm{a}}\end{array}$ & $\begin{array}{l}13.5^{\mathrm{bcd}} \\
21 . .^{\mathrm{bc}} \\
14.3^{\mathrm{bcd}} \\
9.9^{\mathrm{bcd}}\end{array}$ & $\begin{array}{l}18.4^{\mathrm{f}} \\
15.0^{\mathrm{f}} \\
16.8^{\mathrm{f}} \\
16.9^{\mathrm{f}}\end{array}$ & $\begin{array}{c}0.243^{\mathrm{de}} \\
0.328^{\mathrm{de}} \\
0.235^{\mathrm{de}} \\
0.159^{\mathrm{e}}\end{array}$ & $\begin{array}{l}88.3^{\mathrm{abc}} \\
69.6^{\mathrm{abc}} \\
98.5^{\mathrm{abc}} \\
89.1^{\mathrm{abc}}\end{array}$ \\
\hline Helianthus annuus & $\begin{array}{l}28 \mathrm{R} \mathrm{MT} \\
3620 \mathrm{MT} \\
458 \mathrm{MT} \\
\text { R 1954/1 } \\
\text { R } 569 \\
\text { R T2 }\end{array}$ & $\begin{array}{l}1862^{\mathrm{a}} \\
2464^{\mathrm{a}} \\
2025^{\mathrm{a}} \\
1624^{\mathrm{a}} \\
2172^{\mathrm{a}} \\
2403^{\mathrm{a}}\end{array}$ & $\begin{array}{c}7.9^{c d} \\
8.0^{c d} \\
4.8^{d} \\
2.8^{d} \\
8.2^{\text {bcd }} \\
9.3^{\text {bcd }}\end{array}$ & $\begin{array}{l}88.6^{\text {def }} \\
146.2^{\text {bcd }} \\
150.7^{\text {bcd }} \\
210.8^{\text {ab }} \\
123.1^{\text {cd }} \\
102.4^{\text {cde }}\end{array}$ & $\begin{array}{l}0.742^{\text {cde }} \\
1.168^{\text {cde }} \\
0.757^{\text {cde }} \\
0.589^{\text {cde }} \\
0.938^{\text {cde }} \\
0.823^{\text {cde }} \\
\end{array}$ & $\begin{array}{c}116.3^{\mathrm{abc}} \\
88.5^{\mathrm{abc}} \\
90.5^{\mathrm{abc}} \\
107.6^{\mathrm{abc}} \\
119.4^{\mathrm{abc}} \\
114.8^{\mathrm{abc}}\end{array}$ \\
\hline Nicotiana tabacum & $\begin{array}{l}\text { G165 } \\
\text { G19 } \\
\text { P2B }\end{array}$ & $\begin{array}{l}2396^{\mathrm{a}} \\
2180^{\mathrm{a}} \\
1833^{\mathrm{a}}\end{array}$ & $\begin{array}{l}9.5^{b c d} \\
8.9^{b c d} \\
8.8^{b c d}\end{array}$ & $\begin{array}{l}120.4^{\mathrm{cd}} \\
172.7^{\mathrm{bc}} \\
110.4^{\mathrm{cd}}\end{array}$ & $\begin{array}{l}1.236^{\text {cd }} \\
1.490^{c} \\
0.972^{\text {cde }}\end{array}$ & $\begin{array}{l}48.6^{c} \\
46.6^{c} \\
45.9^{c}\end{array}$ \\
\hline Raphanus sativus & $\begin{array}{l}\text { Cavalrondo } \\
\text { Hazera Red } \\
\text { Nabo Amazela } \\
\text { Pegletta }\end{array}$ & $\begin{array}{l}2750^{\mathrm{a}} \\
2595^{\mathrm{a}} \\
2660^{\mathrm{a}} \\
2324^{\mathrm{a}}\end{array}$ & $\begin{array}{l}14.5^{\mathrm{bcd}} \\
35.4^{\mathrm{a}} \\
12.3^{\mathrm{bcd}} \\
19.5^{\mathrm{bc}}\end{array}$ & $\begin{array}{l}210.3^{\mathrm{ab}} \\
102.7^{\text {cde }} \\
279.6^{\mathrm{a}} \\
217.8^{\mathrm{ab}}\end{array}$ & $\begin{array}{c}3.026^{\mathrm{b}} \\
3.287^{\mathrm{b}} \\
3.412^{\mathrm{ab}} \\
4.342^{\mathrm{a}}\end{array}$ & $\begin{array}{l}85.3^{\mathrm{abc}} \\
108.0^{\mathrm{abc}} \\
84.7^{\mathrm{abc}} \\
78.4^{\mathrm{abc}}\end{array}$ \\
\hline
\end{tabular}

a-fDifferent letters indicate significant differences between accessions separately for each parameter $(\mathrm{P}<0.05, \mathrm{~T}$ test $)$. 
The variation of $\mathrm{Cr}$ accumulation in shoots varied from $0.15 \mathrm{ng}$ of Cr per plant in B. carinata variety Commencer 2, to $4.34 \mathrm{ng}$ of $\mathrm{Cr}$ per plant in $R$. sativus variety Pegletta. Variation of $\mathrm{Cr}$ accumulation among genetic material within species was very low and similar among all species varying from 1.4 in $R$. sativus till 2.2 in $B$. juncea. It can be clearly seen a significantly higher accumulation of $\mathrm{Cr}$ in all varieties of $R$. sativus compared to all the other genetic material. On the contrary the other three species of genus Brassica shown the lowest level of $\mathrm{Cr}$ accumulation with mean value of $0.22 \mathrm{ng}$ of $\mathrm{Cr}$ per plant. H. annus and $N$. tabacum showed a middle accumulation capacity of about $0.97 \mathrm{ng}$ of $\mathrm{Cr}$ per plant. However, $\mathrm{Cr}$ accumulations in $H$. annuus and $N$. tabacum were not significantly different from most of the other Brassica spp.

$\mathrm{Cu}$ accumulation in shoots ranged from $0.02 \mathrm{ng}$ of $\mathrm{Cu}$ per plant in $H$. annuus inbred line $\mathrm{R} \mathrm{T} 2$, to $2.29 \mathrm{ng}$ of $\mathrm{Cu}$ per plant in B. carinata variety Gommenzer 1. $\mathrm{Cu}$ accumulation did not show species specific responses and it was very variable even among genetic material within species. However, varieties of $B$. juncea and $B$. napus, and $N$. tabacum cultivars showed a lower degree of differences in $\mathrm{Cu}$ accumulation among genetic material. On the contrary $\mathrm{Cu}$ accumulation differed up to 28 and 36 folds among $R$. sativus and $B$. carinata varieties. In $H$. annuus an exceptionally high variation was found of up to 118 fold due to a very low accumulation in the inbred line R T2. If to not take in account the above inbred line, the variation of $\mathrm{Cu}$ accumulation in among inbred lines of $H$. annuus is reduced only to 2 fold (Table 3 ).

\section{Discussion and conclusions}

Root concentrations were considerably higher than those in the shoot for both $\mathrm{Cr}$ and $\mathrm{Cu}$. Thus, all the plants showed a typical excluder strategy (Hanikenne and Nouet, 2011). In fact, a very small $\mathrm{Cr}$ translocation factor of $0.56 \%$ on average was found (Table 2). However, $\mathrm{Cr}$ concentrations reached considerable levels in shoots $\left(12.6 \mu \mathrm{g} \mathrm{g}^{-1} \mathrm{~d}\right.$.w. on overall species mean) taken into account that normal range of $\mathrm{Cr}$ concentrations found in plants from uncontaminated soils are $0.2-1 \mu \mathrm{g} \mathrm{g}^{-1} \mathrm{~d}$.w. (Nagajyoti et al., 2010). On the contrary, plants from contaminated soils had shown variable $\mathrm{Cr}$ accumulation and up to $490 \mu \mathrm{g} \mathrm{g}^{-1} \mathrm{~d}$.w. but this can be attributed to the soil dust deposited on the leaves as the plants were not properly washed (Jaison and Muthukumar, 2017). These results indicate that the analysed species could be useful for phytoextraction of, but mainly for phytostabilisation, thanks to the progressive removal of the bioavailable form from the substrate (Visconti et al., 2017). For the phytoremediation and biomass purposes it is desirable also that plants survive in the contaminated land and a good indicator of plant stress is its total chlorophyll content. Plants with $\mathrm{Cr}$ in nutrient solutions reduced only a little the total chlorophyll content relatively to control plants indicating little stress under $\mathrm{Cr}$ experiments. Moreover, the main feature of chromium intoxication, which is chlorosis was not observed (Shanker et al., 2005). Although also root $\mathrm{Cu}$ concentrations were considerably higher than those in the shoot, the $\mathrm{Cu}$ translocation

Table 3. Cu concentration in roots and shoots $\left(\mu \mathrm{g} \mathrm{g}^{-1}\right.$ d.w.), shoot d.w. $(\mathrm{mg})$, Cu accumulation in the shoots ( $\mu \mathrm{g}$ d.w.) and relative chlorophyll content (\% of control plants) of 28 analysed accessions from six different species (mean \pm SE, $n=3$ ) after exposure to $2 \mu M$ Cu for six days.

\begin{tabular}{|c|c|c|c|c|c|c|}
\hline Species & Accession name & Root Cu & Shoot $\mathrm{Cu}$ & Shoot d.w. & $\begin{array}{l}\text { Shoot } \mathrm{Cu} \\
\text { accumulation }\end{array}$ & $\begin{array}{l}\text { Relative chlorophyll } \\
\text { content }\end{array}$ \\
\hline Brassica carinata & $\begin{array}{l}79444 \\
\text { B.car } 0.99 \text { (CGN04028) } \\
\text { BRK35 } \\
\text { Gommenzer } 1 \\
\text { Gommenzer } 2 \\
\text { L194252 } \\
\text { SVP nr.12 }\end{array}$ & $\begin{array}{c}24.9^{\mathrm{j}} \\
175.5^{\mathrm{hij}} \\
32.6^{\mathrm{j}} \\
172.7^{\mathrm{hij}} \\
126.1^{\mathrm{hij}} \\
309.2^{\text {efghij }} \\
32.5^{\mathrm{j}}\end{array}$ & $\begin{array}{c}1.4^{\text {ghi }} \\
18.1^{\text {cd }} \\
1.9^{\text {ghi }} \\
17.3^{\text {cde }} \\
13.4^{\text {cdefgh }} \\
0.7^{\text {hi }} \\
14.6^{\text {cdef }}\end{array}$ & $\begin{array}{c}62.6^{\text {bcde }} \\
45.2^{\text {bcde }} \\
50.4^{\text {bcde }} \\
132.6^{\text {abc }} \\
135.4^{\text {ab }} \\
76.1^{\text {abcde }} \\
123.9^{\text {abc }}\end{array}$ & $\begin{array}{c}0.081^{\mathrm{f}} \\
0.81^{\mathrm{bcdef}} \\
0.095^{\mathrm{f}} \\
2.285^{\mathrm{a}} \\
1.771^{\mathrm{ab}} \\
0.064^{\mathrm{f}} \\
1.878^{\mathrm{ab}}\end{array}$ & $\begin{array}{c}88.5^{\mathrm{a}} \\
98.4^{\mathrm{a}} \\
108.6^{\mathrm{a}} \\
82.5^{\mathrm{a}} \\
75.2^{\mathrm{a}} \\
84.4^{\mathrm{a}} \\
100.8^{\mathrm{a}}\end{array}$ \\
\hline Brassica juncea & $\begin{array}{l}\text { Newton } \\
\text { Primus } \\
\text { Trowse } \\
\text { Vitasso }\end{array}$ & $\begin{array}{c}586.9^{\text {def }} \\
712.7^{\text {cd }} \\
317.7^{\text {efghij }} \\
353.8^{\text {efghij }}\end{array}$ & $\begin{array}{c}7.0^{\text {cdefghi }} \\
4.3^{\text {fghi }} \\
5.6^{\text {defghi }} \\
4.1^{\text {fghi }}\end{array}$ & $\begin{array}{l}38.4^{\text {cde }} \\
69.2^{\text {bcde }} \\
61.7^{\text {bcde }} \\
56.2^{\text {bcde }}\end{array}$ & $\begin{array}{l}0.264^{\text {def }} \\
0.287^{\text {cdef }} \\
0.340^{\text {cdef }} \\
0.286^{\text {cdef }}\end{array}$ & $\begin{array}{l}65.5^{\mathrm{a}} \\
117.2^{\mathrm{a}} \\
106.5^{\mathrm{a}} \\
109.6^{\mathrm{a}}\end{array}$ \\
\hline Brassica napus & $\begin{array}{l}\text { Buko } \\
\text { Cobra } \\
\text { Pulsar } \\
\text { Ramses }\end{array}$ & $\begin{array}{c}214.6^{\text {ghij }} \\
462.8^{\text {defgh }} \\
50.1^{j} \\
531.8^{\text {defg }}\end{array}$ & $\begin{array}{c}3.3^{\text {fghi }} \\
5.4^{\text {defghi }} \\
1.5^{\text {ghi }} \\
4.5^{\text {efghi }}\end{array}$ & $\begin{array}{l}90.4^{\text {abcde }} \\
63.4^{\text {bcde }} \\
93.4^{\text {abcde }} \\
53.1^{\text {bcde }}\end{array}$ & $\begin{array}{c}0.252^{\text {def }} \\
0.321^{\text {cdef }} \\
0.164^{f} \\
0.240^{\text {ef }}\end{array}$ & $\begin{array}{l}94.8^{\mathrm{a}} \\
76.2^{\mathrm{a}} \\
85.2^{\mathrm{a}} \\
79.7^{\mathrm{a}}\end{array}$ \\
\hline Helianthus annuus & $\begin{array}{l}28 \mathrm{R} \mathrm{MT} \\
3620 \mathrm{MT} \\
458 \mathrm{MT} \\
\text { R } 1954 / 1 \\
\text { R } 569 \\
\text { R T2 }\end{array}$ & $\begin{array}{c}149.7^{\mathrm{hij}} \\
247.5^{\text {fghij }} \\
119.7^{\mathrm{hij}} \\
175.7^{\mathrm{hij}} \\
172.9^{\mathrm{hij}} \\
79.2^{\mathrm{ij}}\end{array}$ & $\begin{array}{c}13.8^{\text {cdefg }} \\
9.9^{\text {cdefghi }} \\
13.1^{\text {cdefghi }} \\
18.6^{\mathrm{c}} \\
7.4^{\text {cdefghi }} \\
0.3^{\mathrm{i}}\end{array}$ & $\begin{array}{c}135^{\mathrm{ab}} \\
164.7^{\mathrm{a}} \\
116.6^{\mathrm{abc}} \\
69.8^{\mathrm{bcde}} \\
111.2^{\text {abcd }} \\
54.8^{\mathrm{bcde}}\end{array}$ & $\begin{array}{c}1.935^{\mathrm{ab}} \\
1.558^{\mathrm{abc}} \\
1.538^{\mathrm{abcd}} \\
1.221^{\mathrm{abcdef}} \\
0.873^{\mathrm{bcdef}} \\
0.016^{\mathrm{f}}\end{array}$ & $\begin{array}{c}88.8^{\mathrm{a}} \\
63.4^{\mathrm{a}} \\
75.1^{\mathrm{a}} \\
126.9^{\mathrm{a}} \\
76.8^{\mathrm{a}} \\
77.3^{\mathrm{a}}\end{array}$ \\
\hline Nicotiana tabacum & $\begin{array}{l}\text { G165 } \\
\text { G19 } \\
\text { P2B }\end{array}$ & $\begin{array}{l}984.4^{\mathrm{bc}} \\
1525.1^{\mathrm{a}} \\
1105.3^{\mathrm{b}}\end{array}$ & $\begin{array}{c}80.0^{\mathrm{b}} \\
95.0^{\mathrm{a}} \\
87.4^{\mathrm{ab}}\end{array}$ & $\begin{array}{l}20.0^{\text {de }} \\
15.8^{\mathrm{e}} \\
17.0^{\text {de }}\end{array}$ & $\begin{array}{c}1.574^{\mathrm{abc}} \\
1.491^{\mathrm{abcde}} \\
1.485^{\mathrm{abcde}}\end{array}$ & $\begin{array}{c}73.6^{\mathrm{a}} \\
96.6^{\mathrm{a}} \\
137.0^{\mathrm{a}}\end{array}$ \\
\hline Raphanus sativus & $\begin{array}{l}\text { Cavalrondo } \\
\text { Hazera Red } \\
\text { Nabo Amazela } \\
\text { Pegletta }\end{array}$ & $\begin{array}{c}274.4^{\text {fghij }} \\
719.6^{\text {cd }} \\
657.9^{\text {cde }} \\
416.8^{\text {defghi }}\end{array}$ & $\begin{array}{c}1.0^{\text {ghi }} \\
1.0^{\text {ghi }} \\
11.5^{\text {cdefghi }} \\
4.5^{\text {efghi }}\end{array}$ & $\begin{array}{c}124^{\mathrm{abc}} \\
54.6^{\mathrm{bcde}} \\
125.3^{\mathrm{abc}} \\
76.6^{\mathrm{abcde}}\end{array}$ & $\begin{array}{c}0.137^{\mathrm{f}} \\
0.054^{\mathrm{f}} \\
1.539^{\mathrm{abcd}} \\
0.371^{\text {cdef }}\end{array}$ & $\begin{array}{c}96.5^{\mathrm{a}} \\
104.0^{\mathrm{a}} \\
97.7^{\mathrm{a}} \\
90.5^{\mathrm{a}}\end{array}$ \\
\hline
\end{tabular}

a-jifferent letters indicate significant differences between accessions separately for each parameter $(\mathrm{P}<0.05, \mathrm{~T}$ test $)$. 
from roots to shoots was considerably higher compared to that of $\mathrm{Cr}$ experiment with overall mean translocation factor of $13 \%$ (Table 3). This is not surprising as $\mathrm{Cu}$ is also a micronutrient and it has a dedicated homeostasis pathway, while $\mathrm{Cr}$ is a toxic heavy metal with no rule in plant development (Marschner, 2012) and it is possibly actively excluded from the shoots even if it was applied at higher concentrations than $\mathrm{Cu}$. The overall species mean value of $\mathrm{Cu}$ concentration in shoots excluded $N$. tabacum plants was 7.4 $\mu \mathrm{g} \mathrm{g}^{-1} \mathrm{~d}$.w. ranging from $0.3-18.6$ which is in the range of $4-15 \mu \mathrm{g}$ $\mathrm{g}^{-1}$ d.w. typical for plants grown in uncontaminated lands (Nagajyoti et al., 2010). On the contrary $N$. tabacum has great potential for $\mathrm{Cu}$ phytoremediation as it reached high $\mathrm{Cu}$ concentrations in shoots (on average $87.4 \mu \mathrm{g} \mathrm{g}^{-1}$ d.w.) in all three analysed cultivars. This is also demonstrated by its high level of $\mathrm{Cu}$ accumulation even if it was not significantly different from many other genetic materials. However, this is due to a lower biomass value in $N$. tabacum in respect to the other plants which had a faster rate of development. When we collect plants $N$. tabacum was still very small while the other plants developed at a much faster rate and it is believed if to prolong the testing period of $\mathrm{Cu}$ stress, $N$. tabacum would developed much more biomass thus accumulating more $\mathrm{Cu}$. However, $\mathrm{Cu}$ can be also toxic over a certain critical point, that is believed not to have been achieved by plants in our experiment because our $\mathrm{Cu}$ doses were lower than typical critical concentrations encountered in literature (Shahbaz et al., 2010). Moreover, the total chlorophyll content in the $\mathrm{Cu}$ treated plants was only little reduced in comparison to control indicating that plants were still active. To evaluate the ability of a species to extract heavy metals for phytoremediation purposes, the tissue concentrations of shoots alone it is not enough because it does not take plant biomass into consideration (Shahbaz et al., 2010). Species which develop more biomass in stressful condition such as heavy metal contamination are more adapted for non-food biomass production as a strategy for risk management of polluted soils, by avoiding cultivation of food crops. On the same time, species which have higher heavy metal concentrations in their shoot are more adapted for phytoextraction purposes, since they could be able to progressively remove the bioavailable fraction of metals from the soils, thus reducing risks for human health due to PTE entrance into the food chain. Having an intention to reach both purposes, the total shoot accumulation (the product of shoot concentration times biomass) was chosen as a composite index to select the best performing genetic material within each species. All the species appeared to be low accumulators of both $\mathrm{Cr}$ and $\mathrm{Cu}$ thus low phytoextraction capacities are expected for all the genetic material, which is in accordance with the available literature (Han et al., 2004; Shahbaz et al., 2010). On the other hand, a negligible root-to-shoot metal translocation could be very useful in the case of industrial valorisation of aerial crop biomass. Our experiment showed undoubtedly that at low level of available $\mathrm{Cr}$ and $\mathrm{Cu}$ - a typical condition in slightly anthropogenic polluted soils - the majority of the analysed genetic material (except $N$. tabacum cultivars under Cr stress), can grow with little or no stress as shown by good quantity of leaf chlorophyll content relatively to the corresponding leaf chlorophyll content in control leaves. Thus, among the genetic material within each species, we can choose the best performers according to the accumulation coefficient. There is a good correlation between $\mathrm{Cr}$ and $\mathrm{Cu}$ accumulation performance. Therefore, the best performers in $\mathrm{Cr}$ accumulation are also the best performers in $\mathrm{Cu}$ accumulation except in $B$. carinata and in $H$. annuus for one inbred line. This is not surprising as the species were tested in solution under $\mathrm{Cr}$ or $\mathrm{Cu}$ concentrations which were inhibiting the root growth at the same degree of $50 \%$, and $\mathrm{Cu}$ and $\mathrm{Cr}$ have similar atomic and covalent radius. Our observations are in accordance with the references as it was already noted that $\mathrm{Cu}$ and $\mathrm{Cr}$ accumulation in shoots are highly correlated in different varieties of water spinach (Ipomoea aquatic) (He et al., 2015) and within each analysed seaweed species the accumulation of $\mathrm{Cr}$ and $\mathrm{Cu}$ were similar (Murphy et al., 2009). Therefore, it can be supposed, that these two PTEs are following similar stress response pathways in plants.

Taken into account that $\mathrm{Cu}$ is more toxic than $\mathrm{Cr}$ (WHO, 2003a, 2003b; Hemachandra and Pathiratne, 2015), the choice of $B$. carinata and $H$. annuus genetic material to test further under $\mathrm{Cr}$ and $\mathrm{Cu}$ stress in nutrient solution and in $\mathrm{Cr}$ and $\mathrm{Cu}$ contaminated soils should be chosen among best $\mathrm{Cu}$ performers. Moreover, the best performers in $\mathrm{Cr}$ accumulation in B. carinata and H. annuus are not significantly different in $\mathrm{Cr}$ accumulation from varieties or inbred line which are the best performers in $\mathrm{Cu}$ accumulation. Therefore, for each of the analysed species, the two most promising genetic material for phytoremediation of slightly $\mathrm{Cr}$ and $\mathrm{Cu}$ polluted soils and for biomass production are the varieties Gommenzer 1 and SVP nr. 12 of B. carinata, Primus and Trowse of B. juncea, Buko and Cobra of B. napus, Nabo Amazela and Pegletta of $R$. sativus, the inbred lines 28 R MT and 3620 MT of H. annuus, and the cultivars G165 and G19 of N. tabacum.

\section{References}

Cestone B, Quartacci MF, Navari-Izzo F, 2010. Uptake and translocation of CuEDDS complexes by Brassica carinata. Envir. Sci. Tech. 44:6403-8.

Costa M, 2003 Potential hazards of hexavalent chromate in our drinking water. Toxicol. Appl. Pharm. 188:1-5.

EC, 2012. Innovating for sustainable growth. A bioeconomy for Europe. Publications Office of the EU, Luxembourg, 60 pp.

European Community, 2012. Innovating for sustainable growth: a bioeconomy for Europe. $\operatorname{COM}(2012)$ 60, final. Brussels, 13.2.2012.

Fagnano M, 2017. Operative handobook for ecocompatible remediation of degraded soils. LIFE11/ENV/IT/275 Ecoremed. 300 pp.

Fagnano M, Impagliazzo A, Mori M, Fiorentino N, 2015. Agronomic and environmental impacts of giant reed (Arundo donax L.): results from a long-term field experiment in hilly areas subject to soil erosion. Bioenerg. Res. 8:415-22.

Fiorentino N, Fagnano M, Ventorino V, Pepe O, Zoina A, Impagliazzo A, Spigno P, 2013. Assisted phytoextraction of heavy metals: compost and Trichoderma effects on giant reed (Arundo donax L.) uptake and soil N-cycle microflora. Ital. J. Agron. 8:244-54.

Grison C, 2015. Combining phytoextraction and ecocatalysis: a novel concept for greener chemistry, an opportunity for remediation. Environ. Sci. Pollut. Res. 22:5589-91.

Hakan T, Yildiz M, 2015. Interactive effects of sulfur and chromium on antioxidative defense systems and BnMP1 gene expression in canola (Brassica napus L.) cultivars differing in $\mathrm{Cr}(\mathrm{VI})$ tolerance. Ecotoxicology 24:1171-82.

Han FXX, Sridhar BBM, Monts DL, Su Y, 2004. Phytoavailability and toxicity of trivalent and hexavalent chromium to Brassica juncea. New Phytol. 162:489-99.

Hanikenne M, Nouet C, 2011. Metal hyperaccumulation and hypertolerance: a model for plant evolutionary genomics. Curr. Opin. Plant Biol. 14:252-9.

He BY, Ling L, Zhang LY, Li MR, Li QS, Mei XQ, Li H, Tan L, 2015. Cultivar-specific differences in heavy metal $(\mathrm{Cd}, \mathrm{Cr}, \mathrm{Cu}$, 
$\mathrm{Pb}$, and $\mathrm{Zn}$ ) concentrations in water spinach (Ipomoea aquatic 'Forsk') grown on metal-contaminated soil. Plant Soil. 386:251-62.

Hemachandra CK, Pathiratne A, 2015. Assessing toxicity of copper, cadmium and chromium levels relevant to discharge limits of industrial effluents into inland surface waters using common onion, Allium cepa bioassay. Bull. Environ. Contam. Toxicol. 94:199-203.

Jaison S, Muthukumar T, 2017. Chromium accumulation in medicinal plants growing naturally on tannery contaminated and non-contaminated soils. Biol. Trace Elem. Res. 175:223-35.

Lucena JJ, Chaney RL, 2007. Response of cucumber plants to low doses of different synthetic iron chelates in hydroponics. J. Plant Nutr. 30:795-809.

Marchiol L, Assolari S, Fellet G, Zerbi G, 2006. Germination and seedling growth of Indian mustard exposed to cadmium and chromium. Ital. J. Agron. 1:45-9.

Marschner H, 2012. Marschner's mineral nutrition of higher plants. 3rd ed. Elsevier, USA.

Mei B, Puryear JD, Newton RJ, 2002. Assessment of Cr tolerance and accumulation in selected plant species. Plant Soil 247:223-231.

Miretzky P, Cirelli AF, 2010. Cr(VI) and Cr(III) removal from aqueous solution by raw and modified lignocellulosic materials: a review. J. Hazard. Mater. 180:1-19.

Murphy V, Hughes H, McLoughlin P, 2009. Enhancement strategies for $\mathrm{Cu}(\mathrm{II}), \mathrm{Cr}(\mathrm{III})$ and $\mathrm{Cr}(\mathrm{VI})$ remediation by a variety of seaweed species. J. Hazard. Mater. 166:318-26.

Nagajyoti PC, Lee KD, Sreekanth TVM, 2010. Heavy metals, occurrence and toxicity for plants: a review. Environ. Chem. Lett. 8:199-216.

Nita L, Benini L, Ciupagea C, Kavalov B, Pelletier N, 2013. Bioeconomy and sustainability: a potential contribution to the Bioeconomy Observatory. European Commission, Joint Research Centre, Institute for Environment and Sustainability, European Commission.

Prasad MNV, 2014. Engineered phyto-covers as natural caps for containment of hazardous mine and municipal solid waste dump sites - possible energy sources. In: Öztürk M., Ashraf M., Aksoy A., Ahmad M.S.A. (Eds), Phytoremediation for green energy. Springer, The Netherlands.

Prasad MNV, 2015. Phytoremediation crops and biofuels. In: Lichtfouse E. (Ed.), Sustainable agriculture reviews. Vol. 17. Springer, The Netherlands, pp 159-261.

Prasad MNV (ed.), 2016. Bioremediation and bioeconomy. Elsevier, USA.

Shahbaz M, Tseng MH, Stuiver CE, Koralewska A, Posthumus FS, Venema JH, Parmar S, Schat H, Hawkesford MJ, De Kok LJ, 2010. Copper exposure interferes with the regulation of the uptake, distribution and metabolism of sulfate in Chinese cabbage. J. Plant Physiol. 167:438-46.

Shanker AK, Cervantes C, Loza-Tavera H, Avudainayagam S, 2005. Chromium toxicity in plants. Environ. Int. 31:739-53.

Sokal RR, Rohlf FJ, 2010. Biometry. The principles and practice of statistics in biological research. 4th rev. ed. WH Freeman and Company, New York, NY, USA.

Sudhakar P, Latha P, Reddy PV, 2016. Phenotyping crop plants for physiological and biochemical traits. Academic Press Elsevier, Amsterdam, The Netherlands.

USEPA, 1995. EPA Method 3052: Microwave assisted acid digestion of siliceous and organically based matrices. In: Test methods for evaluating solid waste, 3rd ed. USEPA, Washington, DC, USA.

van der Ent A, Baker AJ, Reeves RD, Chaney RL, Anderson CW, Meech JA, Erskine PD, Simonnot MO, Vaughan J, Morel JL, Echevarria G, Fogliani B, Rongliang Q, Mulligan DR, 2015. Agromining: farming for metals in the future? Environ. Sci. Technol. 2015:4773-80.

Visconti D, Fiorentino N, Fagnano M, 2017. Detailed characterisation of contaminated soils: bioassays. In: Fagnano M. (Ed.), Operative handobook for ecocompatible remediation of degraded soils. LIFE11/ENV/IT/275 Ecoremed, pp 70-84.

WHO (World Health Organisation), 2003a. International Health Criteria 61 Chromium. WHO, Geneva, $\mathrm{CH}$. 